\title{
Constructed Wetland System as Secondary Treatment for Stabilization Pond Domestic Effluent
}

\author{
Valdecir dos Santos \\ Serviço Autônomo de Água e Esgoto (SAAE) \\ Av. Comendador Luiz Meneghel, 992 - Centro, 86360-000, Bandeirantes-PR, Brazil \\ E-mail: valsantos_36@hotmail.com
}

Elis Marina Turini Claro Embrapa Gado de Leite, Juiz de Fora-MG

Rua Eugênio do Nascimento, 610 - Dom Bosco, 86038-330, Juiz de Fora-MG, Brazil Tel: 55 (32) 32494860; Fax: 55 (32) 32494826; E-mail: ma_turini@hotmail.com

\section{Renato Nallin Montagnolli}

Department of Biochemistry and Microbiology, UNESP - Univ Estadual Paulista Av. 24-A, 1515 - Bela Vista, 13506-900, Rio Claro-SP, Brazil

Tel: 55 (19) 35264192; Fax: 55 (19) 3526-4176; E-mail: renatonm3@gmail.com

Paulo Renato Matos Lopes

Department of Biochemistry and Microbiology, UNESP - Univ Estadual Paulista Av. 24-A, 1515 - Bela Vista, 13506-900, Rio Claro-SP, Brazil

Tel: 55 (19) 35264192; Fax: 55 (19) 3526-4176; E-mail: lopes.prm@gmail.com

Ederio Dino Bidoia (Corresponding author)

Department of Biochemistry and Microbiology, UNESP - Univ Estadual Paulista

Av. 24-A, 1515 - Bela Vista, 13506-900, Rio Claro-SP, Brazil

Tel: 55 (19) 35264192; Fax: 55 (19) 3526-4176; E-mail: ederio@rc.unesp.br 
Marcelo Henrique Otenio

Embrapa Gado de Leite, Juiz de Fora-MG

Rua Eugênio do Nascimento, 610 - Dom Bosco, 86038-330, Juiz de Fora-MG, Brazil

Tel: 55 (32) 32494860; Fax: 55 (32) 32494826; E-mail: otenio@cnpgl.embrapa.br

Received: March 19, 2013 Accepted: April 16, 2013 Published: June 25, 2013

doi:10.5296/jee.v4i1.3915 URL: http://dx.doi.org/10.5296/jee.v4i1.3915

\begin{abstract}
Alternatives for improving sewage management to avoid degradation and unnecessary waste of hydrological resources are a worldwide concern. Wastewater treatment by the constructed wetlands process using macrophytes is considered a robust system, due to its low cost and straightforward means of operation and repair. In this study, a horizontal flow constructed wetland system performance is evaluated. The system applied cattail as secondary treatment for a stabilization pond in a sewer treatment plant. Basically, these systems are based on channels filled with highly porous media, which detains high hydraulic conductance, providing the right support for macrophyte and biofilm growth. The horizontal flow constructed wetland revealed superior capacity and stability when removing COD, BOD, phosphorous and Escherichia coli. Also, cattail macrophyte developed in medium conditions where it was inserted. The results allowed a better comprehension about the phenomena associated to constructed wetlands pollutant removal capabilities.
\end{abstract}

Keywords: Wastewater, Secondary treatment, Typha sp, Constructed wetland, Domestic effluent 


\section{Introduction}

In the last few decades, environmental pollution has become a public matter in both developed and third world countries. The reason behind such awareness is due to a rapid economic development intensely related to natural resources exploration, which had been previously left untouched (Mant et al., 2005).

The lack of potable water is a growing issue, both in terms of quantity and quality, which has lead humanity to look for many alternatives in order to improve water management and its persistence in our environment (Conte and Leopoldo, 2001). Sewage treatment seeks a way to avoid degradation and unnecessary waste of hydrological resources, thus becoming an important matter in Brazilian water treatment (Tonetti et al., 2009).

Amongst many alternatives, wastewater treatment by the constructed wetlands process using macrophytes is considered a robust system, due to its low cost and straightforward means of operation and repair. Such features fit perfectly the climatic conditions of tropical countries which have available areas where these systems can be implemented, as in Brazil (Brasil and Matos, 2008).

Basically, these systems are based on channels filled with highly porous media, which detain high hydraulic conductance (usually gravel or thick sand), providing the right support for macrophyte and biofilm growth, besides the fundamental role as a filter to some pollutants. The constructed wetlands are divided according to their flow, which can be either vertical or horizontal and surface or subsurface (Calijuri et al., 2009).

Studies involving real-scale and contained experiments have shown that built wetlands have some important capabilities related to the reduction of organic matter, suspense solids, nitrogen, phosphorous and pathogenic organisms. This decrease is caused by the combined activity of many factors, such as: sedimentation, filtration, precipitation and chemical adsorption, as well as microbial and vegetable interactions. Constructed wetlands are broadly used in various countries as an ultimate resolution in wastewater treatment and improvement, when it comes to river and lake water (Pereira et al., 2007).

In this study, a horizontal flow constructed wetland system performance is evaluated. The system was built in pilot scale with cattail (Typha sp.) as secondary treatment for a stabilization pond in a sewer treatment plant located at Bandeirantes-PR, Brazil. The purpose was to verify the ability of the wetland to decrease physical-chemical and microbiological parameters, such as color, turbidity, organic matter, conductivity, biochemical oxygen demand (BOD), chemical oxygen demand (COD), phosphorous, nitrogen, total coliforms and Escherichia coli.

\section{Materials and Methods}

The experiment proposed in this study was implemented in a sewer treatment plant located at Bandeirantes-PR, Brazil. The local population is composed of 33,732 inhabitants, of which 27,220 represent the urban citizens, and the other 6,012 represent the rural population. This population is found in a $444.3 \mathrm{~km}^{2}$ area, whereas $12 \mathrm{~km}^{2}$ is the urban area (PMB, 2005). 


\section{Macrothink}

Journal of Environment and Ecology

ISSN 2157-6092

2013, Vol. 4, No. 1

This city owns a sewer network which reaches $98 \%$ urban sewage capture and treatment. Treatment in this network is done by auto depuration processes, stabilization ponds and dual anaerobic ponds systems followed by a facultative pond. The station is located near the "Ribeirao das Antas" river, where the treated wastewater is released.

In order to accomplish the secondary treatment proposed, part of the effluent from the stabilization ponds was used. The wetland was built in pilot scale, above ground, in cement blocks with impermeable internal walls with the following dimensions: $0.65 \mathrm{~m}$ height, $0.60 \mathrm{~m}$ substrate height, $1.30 \mathrm{~m}$ width, $2.15 \mathrm{~m}$ length and $1.82 \mathrm{~m}^{2}$ surface area (Figure 1); functioning in horizontal substrate flow and vertical percolation with an escape system in the lower area.

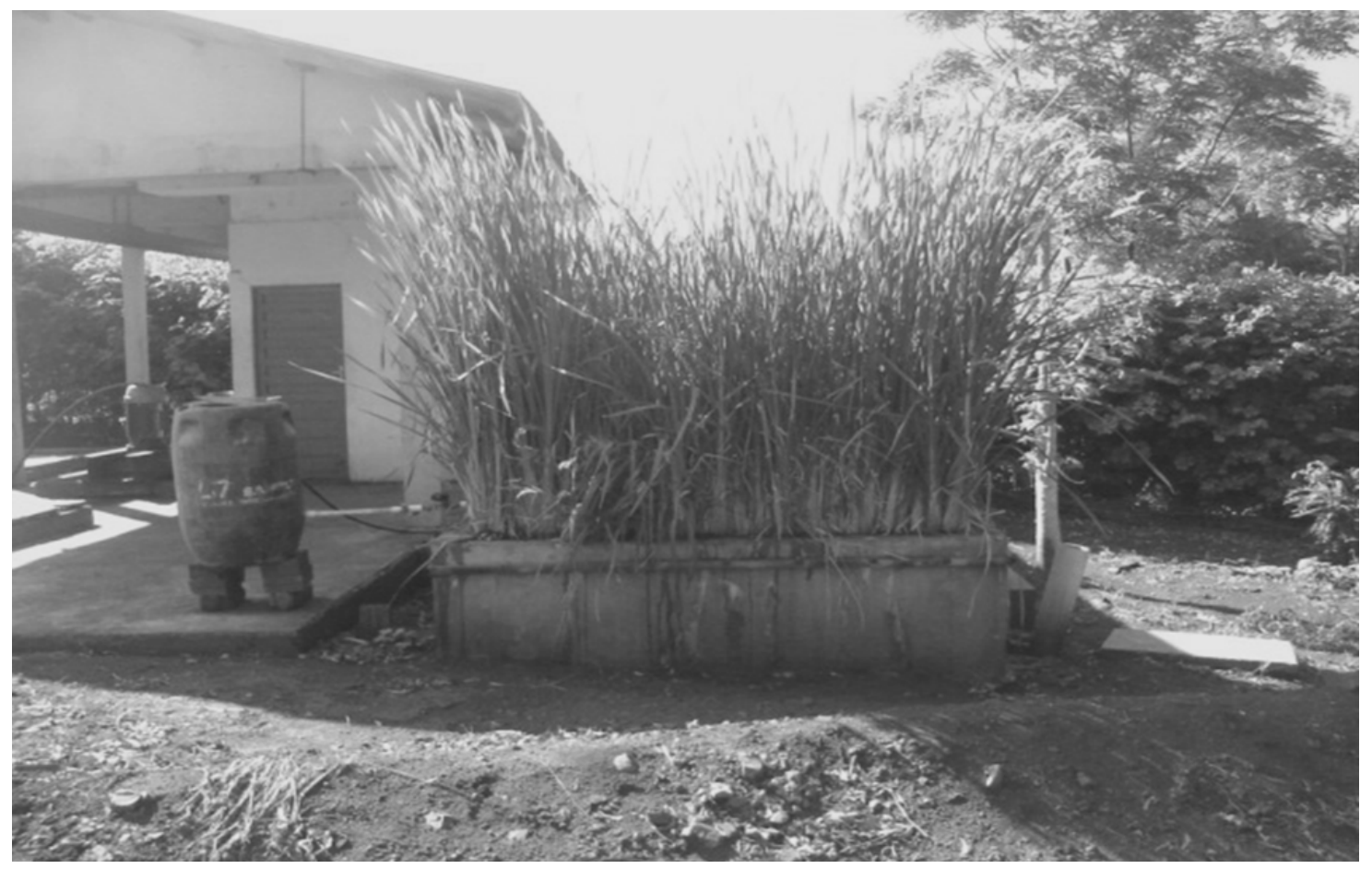

Figure 1. Constructed wetland system of horizontal flow installed in stabilization pond (sewage treatment station of Bandeirantes-PR, Brazil). On the left, there is the reservoir connected to the hydraulic loading rate (HLR) control.

The waterbed was composed of four $10 \mathrm{~cm}$ gravel layers with " $3,2,1$ and small rock" gradations with pre-filtering functions, a $10 \mathrm{~cm}$ sand layer (granulometrics ranging from 15 to $20 \mathrm{~mm}$ ) and a rice straw layer in the upper part. Some samples of the macrophyte grown in waterbeds (Typha sp.) were manually taken from their natural environment in an area near the sewer treatment plant. The total biomass was circa $15 \mathrm{~kg}$.

Effluent to be treated from the stabilization pond was conducted by gravity through pipes towards a $200 \mathrm{~L}$ reservoir, followed by an input volume control hydrometer and then disposed in the first waterbed parts, denominated input zone, by four perforated hoses disposed in parallel, in a closed circuit, from where it slowly percolated through the filtering material all the way to the final area, denominated output zone. This percolation had a 
propensity to flow horizontally using impulse from a bottom declivity. The output tubes were connected to a flexible hose placed there to control the effluent level inside the waterbed. A maximum hydraulic loading rate (HLR) was $260 \mathrm{~cm} . \mathrm{d}^{-1}$, with minimum values adjusted to $100 \mathrm{~cm} \cdot \mathrm{d}^{-1}$ (Figure 2).

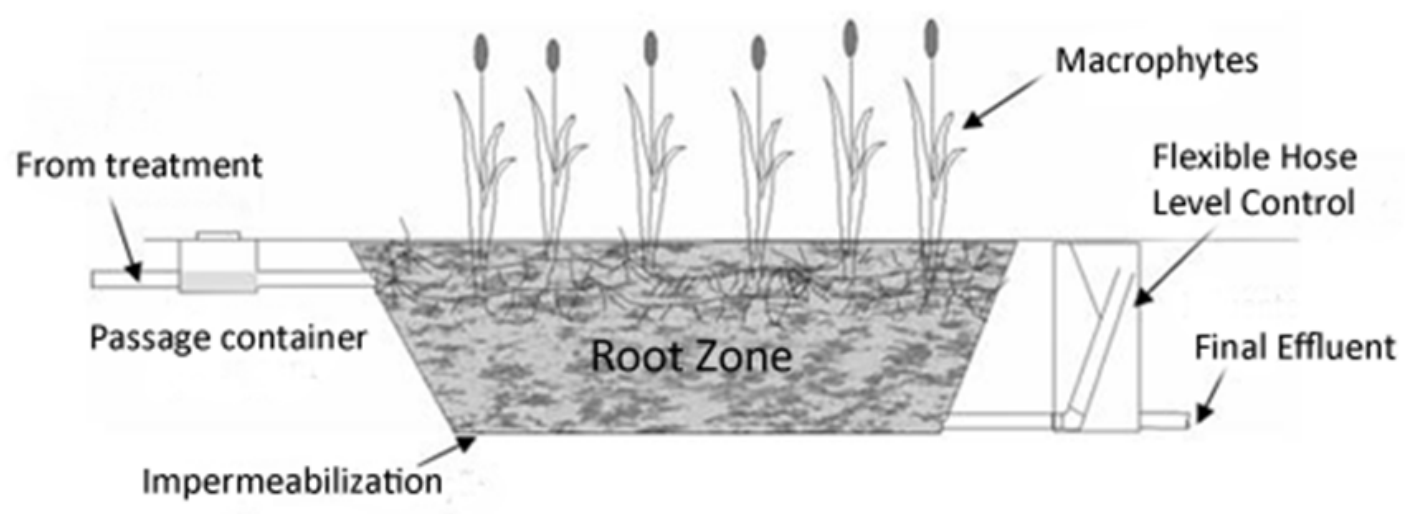

Figure 2. Constructed wetland system scheme with macrophytes according to Sezerino (2006).

In order to perform this study in the time period between June 2005 and October 2005, an effluent output monitoring program was consolidated in the stabilization pond and in the wetland outputs, consisting of a weekly sampling and physical-chemical analysis, and also microbiological tests, carried out in the water and sewage analysis laboratory at "Estação de Tratamento de Água - ETA" (Water Treatment Plant) of "Serviço Autônomo de Água e Esgoto (SAAE)" - Bandeirantes - Paraná - Brazil. The experiment was carried out at an average $21^{\circ} \mathrm{C}$ temperature environment.

According to "Standard Methods for the Examination of Water and Wastewater" (APHA, 2000), Branco (1978) and CETESB (1986), the following parameters were evaluated: $\mathrm{pH}$, conductivity, biochemical oxygen demand (BOD), chemical oxygen demand (COD), color, phosphorous, nitrogen, dissolved oxygen, turbidity, precipitated solids, alkalinity, total hardness, coliforms and Escherichia coli.

\section{Results}

Tables 1 and 2 present the average performance results of the wetland, which received effluent from the stabilization pond, with a hydraulic loading rate (HLR) of $260 \mathrm{~cm} . \mathrm{d}^{-1}$ and $100 \mathrm{~cm} . \mathrm{d}^{-1}$ during the monitoring period.

According to Tables 1 and 2, there were no major changes in $\mathrm{pH}$ values in both analyzed areas, regardless of HLR, similar to the studies by Mant et al. (2005) and Prochaska et al. (2007). This indicates the existence of a buffer system which stabilizes the $\mathrm{pH}$ and thereby maintains the processes and chemical reactions in progress (Bastos et al., 2010).

Table 1. Percentage and values of removal under the samples with HLR of $260 \mathrm{~cm} \cdot \mathrm{d}^{-1}$ 


\begin{tabular}{|c|c|c|c|}
\hline Parameters & $\begin{array}{l}\text { Stabilization } \\
\text { Pond Output }\end{array}$ & $\begin{array}{c}\text { Wetland } \\
\text { Output }\end{array}$ & $\begin{array}{c}\text { Removal } \\
\text { Efficiency } \\
(\%)\end{array}$ \\
\hline pH & 7.4 & 7.1 & - \\
\hline Color APHA Pt/Co & 479 & 307 & 35.90 \\
\hline Dissolved Oxygen & 2.31 & 2.61 & - \\
\hline Turbidity (FTU) & 58.10 & 44.73 & 23.01 \\
\hline Alkalinity (mg CaCO$\left.{ }_{3} \cdot L^{-1}\right)$ & 237 & 277 & - \\
\hline Hardness (mg CaCO$\left.{ }_{3} \cdot \mathrm{L}^{-1}\right)$ & 137 & 193 & - \\
\hline $\begin{array}{l}\text { Organic Matter }\left(\mathrm{mg} \cdot \mathrm{L}^{-1} \text { of } \mathrm{O}_{2}\right. \\
\text { consumed) }\end{array}$ & 31.76 & 25.33 & 20.24 \\
\hline Settleable Solids (mL . $\left.\mathbf{L}^{-1}\right)$ & 0.3 & 0 & - \\
\hline Conductivity $(\boldsymbol{\mu} S)$ & 557 & 591 & - \\
\hline $\operatorname{COD}\left(\mathrm{mg} \mathrm{O}_{2} \cdot \mathrm{L}^{-1}\right)$ & 266.33 & 122.55 & 53.98 \\
\hline $\mathrm{BOD}\left(\mathrm{mg} \mathrm{O} \mathrm{O}_{2} \cdot \mathrm{L}^{-1}\right)$ & 75 & 61.86 & 17.52 \\
\hline Nitrogen $\left(\mathbf{m g} \cdot \mathrm{L}^{-1}\right)$ & 31.11 & 28.33 & 8.93 \\
\hline Phosphorous (mg . $\left.\mathrm{L}^{-1}\right)$ & 14.35 & 12.90 & 10.10 \\
\hline Total Coliforms (UFC .100 mL $\mathrm{mL}^{-1}$ ) & 927 & 139,5 & 84.95 \\
\hline Escherichia coli (UFC .100 $\left.\mathrm{mL}^{-1}\right)$ & 351 & 38 & 89.17 \\
\hline
\end{tabular}

Table 2. Percentage and values of removal under the samples with HLR of $100 \mathrm{~cm} \cdot \mathrm{d}^{-1}$

\begin{tabular}{|c|c|c|c|}
\hline Parameters & $\begin{array}{l}\text { Stabilization } \\
\text { Pond Output }\end{array}$ & $\begin{array}{l}\text { Wetland } \\
\text { Output }\end{array}$ & $\begin{array}{c}\text { Removal } \\
\text { Efficiency } \\
(\%)\end{array}$ \\
\hline pH & 7.5 & 7.0 & - \\
\hline Color APHA Pt/Co & 428 & 230 & 46.26 \\
\hline Dissolved Oxygen & 3.46 & 4.06 & - \\
\hline Turbidity (FTU) & 69.64 & 26.92 & 61.34 \\
\hline Alkalinity (mg CaCO$\left.{ }_{3} . \mathrm{L}^{-1}\right)$ & 217 & 236 & - \\
\hline Hardness (mg CaCO$\left.{ }_{3} . \mathrm{L}^{-1}\right)$ & 118 & 132 & - \\
\hline $\begin{array}{l}\text { Organic Matter }\left(\mathrm{mg} \cdot \mathrm{L}^{-1} \text { of } \mathrm{O}_{2}\right. \\
\text { consumed) }\end{array}$ & 39.83 & 17.66 & 55.66 \\
\hline Settleable Solids (mL . $\left.\mathbf{L}^{-1}\right)$ & 0.2 & 0 & - \\
\hline Conductivity $(\boldsymbol{\mu} S)$ & 521 & 566 & - \\
\hline $\mathrm{COD}\left(\mathrm{mg} \mathrm{O} \mathrm{O}_{2} \cdot \mathrm{L}^{-1}\right)$ & 275.50 & 99.83 & 63.76 \\
\hline $\mathrm{BOD}\left(\mathrm{mg} \mathrm{O} \mathrm{O}_{2} \cdot \mathrm{L}^{-1}\right)$ & 112.0 & 31.55 & 71.95 \\
\hline Nitrogen $\left(\mathrm{mg} \cdot \mathrm{L}^{-1}\right)$ & 27.42 & 25.14 & 8.31 \\
\hline
\end{tabular}




\begin{tabular}{|c|c|c|c|}
\hline Phosphorous (mg . $\mathrm{L}^{-1}$ ) & 15.51 & 10.64 & 31.39 \\
\hline Total Coliforms (UFC .100 mL ${ }^{-1}$ ) & 321,5 & 58,5 & 81.80 \\
\hline Escherichia coli $\left(\mathrm{UFC} .100 \mathrm{~mL}^{-1}\right)$ & 141,5 & 20,1 & 85.79 \\
\hline
\end{tabular}

Concerning the wetlands effluent electrical conductivity, both application rates varied from 521 to $591 \mu \mathrm{S}$, below the 661 to $801 \mu \mathrm{S}$ values obtained by Nogueira et al. (2005), who worked with a vertical flow wetland. Conductivity values were beneath the $700 \mu \mathrm{S}$, thus compatible with conditions for cattail establishment, presenting problems only when in a $40 \mu \mathrm{S} . \mathrm{cm}^{-1}$ environment (Brasil et al., 2005).

When the HLR was decreased, the effectiveness in color and turbidity reduction increased about $46.26 \%$ and $61.34 \%$, respectively. This result was due to algae retention, since it can associate with the high occurrence of greenish effluent in the stabilization pond.

\section{Discussion}

The constructed wetland removed, for maximum efficiency, the organic matter with HLR of $100 \mathrm{~cm} \cdot \mathrm{d}^{-1}$. Suspended, settleable or soluble organic matter removal is generally very high in built wetlands and it occurs by physical and biological processes. These methods include sedimentation, which usually occurs owing to the low flow pace; and filtration, due to the presence of roots and rhizomes and bacteria growth in liquid medium and adhered to biofilm, degrading these pollutants (Calijuri et al., 2009).

Among the parameters that could influence the reduced performance in organic matter removal with $260 \mathrm{~cm} . \mathrm{d}^{-1}$ of HLR, hydrodynamic issues should be considered. A water preferential pathway may have occurred and the contact between effluent and sludge may have been reduced, causing a deficient treatment.

In a HLR of $100 \mathrm{~cm} . \mathrm{d}^{-1}$, COD and BOD values respectively decreased $63.76 \%$ and $71.95 \%$, and the reduction was higher with $260 \mathrm{~cm} . \mathrm{d}^{-1}$ of HLR. These results supported the need for HLRs adjustment, which demonstrated that with prolonged retention, the metabolic activity had a high efficiency.

According to Watson et al. (1989) loading rates vary according to each treatment type, project objectives, system types and configurations, as well as performance levels. Surface flow systems typically are loaded less than subsurface systems. HLRs for acid mine drainage systems range from 0.810 to $8,640 \mathrm{~cm} . \mathrm{d}^{-1}$ for example. A rule of thumb of $29.40 \mathrm{~cm} . \mathrm{d}^{-1}$ has only been suggested, but is not representative of every situation.

Chang et al. (2007), evaluated the effect of HLR on the removal of water pollutants. The removal of ammonium, total phosphate, COD and BOD showed minor negative response to an increase in HLR from 20 to $1200 \mathrm{~cm} \cdot \mathrm{d}^{-1}$, while the mass removal rate showed a markedly positive response to HLR. Also, there was no upper limit for mass loading rates when HLR was increased to $120 \mathrm{~cm} \cdot \mathrm{d}^{-1}$. Values up to $541 \mathrm{~cm} \cdot \mathrm{d}^{-1}$ have been reported by Schulz et al. (2003).

According to Otenio et al. (2007), the treatment enabled the effluent release in "Ribeirão das 
Antas", a class 4 river based on CONAMA 357/2005 (Brazil, 2005). Moreover, as shown in Tables 1 and 2, because of the COD and BOD variability of the stabilization pond effluent in different HLRs, the treatment (constructed wetland) improved the physical-chemical and microbiological profile of the effluent to be released.

Tomazela et al. (1999) used water hyacinth (Eichhornia crassipes) for final treatment of domestic effluent previously decanted and obtained a COD reduction of $86.87 \%$. Also, Prochaska et al. (2007) decreased by $92 \%$ the COD in a final treatment of domestic effluent using a vertical flow with Phragmites australis.

With regard to phosphorous, the cattail wetland was able to reduce $31.39 \%$ in HLR of $100 \mathrm{~cm} . \mathrm{d}^{-1}$. This can be attributed to free phosphorous absorption by Typha sp., which had a high growth ratio (leaves and roots).

According to Mazzola et al. (2005), phosphorus removal from the environment occurs through adsorption promoted by decomposing organic matter, insoluble compounds formed with iron and manganese and also by plant absorption. This agrees with Mant et al. (2005), who suggested that phosphorous reacts quickly with a wide variety of surfaces that associate it with a complex reaction series of adsorption and dissociation.

Phosphorous is a basic component that stores and transfers energy to the plant and any metabolic processes occur in its absence. Also, the formation of complexes in phosphorous fixation must be avoided owing to the plant's inability to absorb these compounds. Three parameters contribute to maintain phosphorus availability in the plant: $\mathrm{pH}$ establishment in neutral conditions, appropriate soil aeration and permanent incorporation of organic matter. All circumstances allow a humification that increases buffering and enables phosphorous to become available to plants (Sousa et al., 2005).

Prochaska et al. (2007) obtained a phosphorous removal level reaching 64\% with Phragmites australis, while Mazzola et al. (2007) removed 30\% of phosphorous in $72 \mathrm{~h}$ treatment using Typha sp. in a vertical flow anaerobic reactor.

With regard to the decreased nitrogen values (Tables 1 and 2), the removal was higher in HLR of $260 \mathrm{~cm} \cdot \mathrm{d}^{-1}$. The main processes involved in constructed wetlands were: vegetal and microbiological biomass storage, insoluble compounds precipitation and adsorption to the substrate (Calijuri et al., 2009). There is a symbiotic relationship between plants and bacteria through a mechanism that is not yet very clear, which may justify the elements assimilation such as phosphorus and nitrogen by plants and biofilms (Mant et al., 2005).

The removal of total coliforms and E. coli was high and greater in $260 \mathrm{~cm} / \mathrm{d}$ of HLR, reaching $84.95 \%$ and $89.17 \%$, respectively (Tables 1 and 2). However, the results using a HLR of $100 \mathrm{~cm} . \mathrm{d}^{-1}$ were also elevated and indicate the effectiveness of the system.

In corroboration with these results, Bastos et al. (2010) presented an Escherichia coli removal efficiency of $99.96 \%$ in a septic tank followed by wetland treatment. Hence, Calijuri et al. (2009) treated a UASB reactor effluent with horizontal flow wetland and they showed a major percentage removal in E. coli of $99.72 \%$ to $99.99 \%$. 
Determinant mechanisms and parameters in coliform removal from constructed wetlands includes temperature, plant roots and biofilm retention, organic matter adsorption, predation, completion and natural death, consequences of biocide effects from macrophytes byproducts and solar radiation. Yet even then, there are no consolidated prediction models of bacterial decay on constructed wetlands (Calijuri et al., 2009).

\section{Conclusion}

Natural systems are featured technological alternatives in sewage treatment when it comes to sustainability, presenting an improved nutrient cycling; reduced byproducts production; rural landscape fitting; low implementation, operation and repair costs; and efficient sewer disinfection without the addition of chemicals, allowing reutilization of the effluent. These facts demonstrate the necessity of valuing treated sewage.

Under operational conditions tested in this study, the horizontal flow constructed wetland revealed superior capacity and stability when removing COD, BOD, phosphorous and Escherichia coli, confirming well known references in this field of study. The treatment was successful in showing a global well performed treatment, according to expectations in the scope of what was previously projected.

Typha sp macrophyte presented a great development and adaptation to the medium conditions where it was inserted, determined by wastewater characteristics.

Results obtained indicate the need for complementary studies, in order to better understand the phenomena and mechanisms associated to nutrient and coliform removal from constructed wetlands. Such data is important to assist in the formulation of improved dimensioning criteria.

\section{Acknowledgement}

The authors thank the "Serviço Autônomo de Água e Esgoto (SAAE)", Bandeirantes-PR, Brazil, for support.

\section{References}

American Public Health Association - APHA. (2000). Standard methods for the examination of water and wastewater (20th ed). American Public Health Association: Washington.

Bastos, R. K., Calijuri, M. L., Bevilacqua, P. D., Rios, E. N., Dias, E. H., Capelete, B. C., \& Magalhães, T. B. (2010). Post-treatment of UASB reactor effluent in waste stabilization ponds and in horizontal flow constructed wetlands: a comparative study in pilot scale in Southeast Brazil. Water Science and Technology, 61, 995-1002. http://dx.doi.org/10.2166/wst.2010.960

Branco, S. M. (1978). Hidrobiologia Aplicada à Engenharia Sanitária (Hydrobiology Applied to Sanitary Engineering). BNH/ABES/CETESB: São Paulo.

Brasil, M. S., \& Matos, A. T. (2008). Avaliação de espectos hidráulicos e hidrológicos de sistemas alagados construídos de fluxo subsuperficial. Engenharia Sanitária e Ambiental (Sanitary Engineering Journal), 13, 323-328 
Brasil, M. S., Matos, A. T., Soares, A. A., \& Ferreira, P. A. (2005). Qualidade do efluente de sistemas alagados construídos, utilizados no sistema de tratamento de esgoto doméstico. Revista Brasileira de Engenharia Agrícola e Ambiental (Brazilian Journal of Agricultural and Environmental Engineering), 9, 133-137

BRAZIL. Conselho Nacional do Meio Ambiente - CONAMA (2005) Resolução $n^{\circ}$ 357, de 17 de março de 2005, Brasília, Brazil.

Calijuri, M. L., Bastos, R. K. X., Magalhaes, T. B., Capelete, B. C., \& Dias, E. H. O. (2009). Tratamento de esgotos sanitários em sistemas reatores UASB/wetlands construídas de fluxo horizontal: eficiência e estabilidade de remoção de matéria orgânica, sólidos, nutrientes e coliformes. Engenharia Sanitária e Ambiental (Sanitary Engineering Journal), 14, 421-430

Chang, J., Zhang, X., Perfler, R., Xu, Q., Niu, X., \& Ge, Y. (2007). Effect of hydraulic loading rate on the removal efficiency in a constructed wetland in subtropical China. Fresenius Environmental Bulletin, 16, 1082-1086

Companhia de Tecnologia de Saneamento Ambiental - CETESB. (1986). Contagem Padrão de Colônias de Bactérias, Norma Técnica L5.201. BNH/ABES/CETESB: São Paulo.

Conte, M. L., \& Leopoldo, P. R. (2001). Avaliação de recursos hídricos: Rio Pardo, um exemplo (Water resources assessment: Rio Pardo, an example). Editora UNESP: São Paulo, Brazil.

Mant, C., Costa, S., Williams, J., \& Tambourgi, E. (2005). Studies of removal of chromium by model constructed wetland. Brazilian Journal of Chemical Engineering, 22, 381-387. http://dx.doi.org/10.1590/S0104-66322005000300007

Mazzola, M., Roston, D. M., \& Valentim, M. A. A. (2005). Uso de leitos cultivados de fluxo vertical por batelada no pós-tratamento de efluente de reator anaeróbio compartimentado. Revista Brasileira de Engenharia Agrícola e Ambiental (Brazilian Journal of Agricultural and Environmental Engineering), 9, 276-283

Nogueira, S. F., Carmo, J. B., Montes, C. R., Victória, R. L., Ravagnani, E. C., \& Barufaldi, R. O. (2005). Indicadores eco-fisiológicos da qualidade de um solo irrigado com esgoto tratado. Revista Brasileira de Engenharia Agrícola e Ambiental (Brazilian Journal of Agricultural and Environmental Engineering), 9, 138-142.

Otenio, M. H., Ravanhani, C., Panchoni, L. C., Cruz, G. C. A., Silva, L. R., \& Santos, V. (2007). Impacto dos sistemas agropecuários e de centros urbanos na qualidade da água superficial. Anais do $6^{\circ}$ Congresso Internacional do Leite [CD-ROM], Resende, Brazil, Dec 4-6, EMBRAPA.

Pereira, M. G., Silva, D. A., Andrade Neto, C. O., Brito, L. P., \& Melo, H. N. S. (2207). Uso de alagado construído (wetland) no condicionamento de efluente de lagoa de estabilização para fins de reuso na agricultura no semi-árido nordestino. Revista AIDIS, 1.

Prefeitura Municipal de Bandeirantes - PMB. (2005). Inventário Turístico, Secretaria da Indústria, Comércio e Turismo: Paraná. 


\section{Macrothink}

Prochaska, C. A., Zouboulis, A. I., \& Eskridge, K. M. (2007). Performance of pilot-scale vertical-flow constructed wetlands, as affected by season, substrate, hydraulic load and frequency of application of simulated urban sewage. Ecological Engineering, 3, 57-66. http://dx.doi.org/10.1016/j.ecoleng.2007.05.007

Schulz, C., Gelbrecht, J., \& Rennert, B. (2003). Treatment of rainbow trout farm effluents in constructed wetland with emergent plants and subsurface horizontal water flow. Aquaculture, 217, 207-221. http://dx.doi.org/10.1016/S0044-8486(02)00204-1

Sousa, J. T., Haandel, A. C., Cavalcanti, P. F. F., \& Figueiredo, A. M. F. (2005). Tratamento de esgoto para uso na agricultura do semi-árido nordestino. Engenharia Sanitária e Ambiental (Sanitary Engineering Journal), 10, 260-265

Tomazela, A. B. G., Leopoldo, P. R., Breda, C. C., \& Piedade, A. R. (1999). Tratamento de efluentes domésticos em zona rural através do uso de sistemas com plantas aquáticas. Arquivos do Instituto Biológico (Archives of Instituto Biológico), 66, 82-82

Tonetti, A. L., Cerqueira, R. S., Couracci Filho, B., Von Sperling, M., \& Figueiredo, R. F. (2009). Tratamento de esgotos de pequenas comunidades pelo método do escoamento superficial do solo. Teoria e Prática na Engenharia Civil (Theory and Practice in Civil Engineering), 13, 69-79

Watson, J. T., Reed, S. C., Kadlec, R. H., Knight, R. L., \& Whitehouse, A. E. (1989). Constructed wetlands for wastewater treatment: municipal, industrial and agricultural. Lewis Publishers: Michigan. 